ARAŞTIRMA / RESEARCH

\title{
Fear of COVID-19 among healthcare workers in filiation teams: predictive role of sociodemographic, organizational and resilience factors
}

Filyasyon ekibindeki sağlık çalışanlarında COVID-19 korkusu: sosyodemografik, organizasyonel ve dayanıkl1lı faktörlerinin tahmin edici rolü

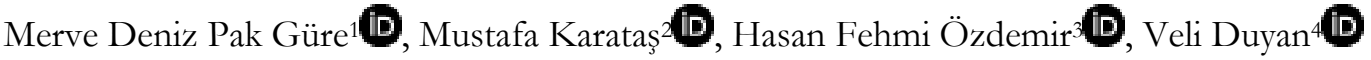 \\ ${ }^{1}$ Başkent Üniversitesi, Sağlık Bilimleri Fakültesi, Sosyal Hizmet Bölümü, Ankara, Turkey \\ 2İstanbul Sabahattin Zaim Üniversitesi, Sağlık Bilimleri Fakültesi, Sosyal Hizmet Bölümü, İstanbul, Turkey \\ ${ }^{3}$ Ankara Üniversitesi, Sürekli Eğitim Merkezi, Ankara, Turkey \\ ${ }^{4}$ Ankara Üniversitesi, Sağlık Bilimleri Fakültesi, Sosyal Hizmet Bölümü, Ankara, Turkey
}

\section{Abstract}

Purpose: The study aims to examine the effects of sociodemographic, organizational, and resilience factors on the fear of COVID-19 of healthcare workers in the filiation teams.

Materials and Methods: 1028 healthcare workers participated in the study. The sociodemographic questionnaire, The Fear of COVID-19 Scale, and The Resilience Scale for Adults were used. The data were analysed with stepwise multiple linear regression by using the backward elimination method.

Results: The study showed that age and family cohesion are positively significant, while planned future and perception of self are negatively significant explanatory factors on the fear of COVID-19. The fear of COVID-19 is higher in females, and in those; with a high level of education, who have an individual with a chronic disease at home, with a low-income level, who lost a colleague or a family member due to coronavirus, who have an increase in patient burden, and who have problems in access to medical equipment.

Conclusion: It is recommended to improve psychosocial support and organizational conditions for healthcare workers in the filiation teams.

Keywords: Mental health, COVID-19, health personnel, fear, filiation teams, resilience

\section{Öz}

Amaç: Çalışma, filyasyon ekiplerinde görev yapan sağlık çalışanlarının sosyodemografik, örgütsel ve yılmazlık faktörlerinin COVID-19 korkusu üzerindeki etkisini incelemeyi amaçlamaktadır.

Gereç ve Yöntem: Çalıșmava 1028 sağlık çalıșanı katılmıştır. Verilerin toplanmasında sosyodemografik soru formu, COVID-19 Korkusu Ölçeği ve Yetişkinler için Dayanıklılık Ölçeği kullanılmıştır. Veriler, geriye doğru eleme yöntemi kullanılarak adım adım çoklu doğrusal regresyon ile analiz edilmiştir.

Bulgular: Çalışma, COVID-19 korkusu üzerinde yaş ve aile uyumunun olumlu, planlanmış gelecek ve benlik algısının olumsuz anlamlı açıklayıcı faktörler olduğunu göstermiştir. Kadınlarda COVID-19 korkusu daha yüksektir. Eğitim düzeyi yüksek, evde kronik hastalı̆ga sahip bireyi olan, gelir düzeyi düșük, meslektaşını ya da ailesinden birini koronavirüs nedeniyle kaybetmiş, hasta yükünde artış olan, sağlık sorunu yaşayanlarda ve tıbbi ekipmana erişim engelleri olanlarda COVID-19 korkusu artmaktadır.

Sonuç: Filyasyon ekiplerinde sağlık çalışanlarının psikososyal açıdan desteklenmesi ve organizasyonel koşulların iyileştirilmesi önerilmektedir.

Anahtar kelimeler: Ruh sağllğı, COVID-19, sağlik çalışanları, korku, filyasyon ekipleri, dayanıklılık

Yazışma Adresi/Address for Correspondence: Dr. Veli Duyan, Ankara Üniversitesi, Sağlık Bilimleri Fakültesi, Sosyal Hizmet Bölümü, Ankara, Turkey, E-mail: vduyan@health.ankara.edu.tr

Geliş tarihi/Received: 02.08.2021 Kabul tarihi/Accepted: 07.10.2021 Çevrimiçi yayın/Published online: 27.10.2021 


\section{INTRODUCTION}

The COVID-19 pandemic has led to a new public health crisis threatening the world. Healthcare workers constitute the most affected population group in the fight against the COVID-19. There are physical, psychosocial, and economic aspects among these effects ${ }^{1,2}$. Especially, the COVID-19 pandemic has brought with it an important challenge for the mental health of healthcare workers. In terms of psychosocial aspects, the increased workload, witnessing worsening health conditions, being obliged to wear protective clothing, having to spend less time with the family, being exposed to discrimination by the social environment bring serious difficulties to healthcare workers both in business and social life ${ }^{3-5}$. Anxiety, distress, panic, depression, anger, confusion, indecision, and burnout increases in healthcare workers during the pandemic process are reported in studies ${ }^{6-8}$. It is also stated that the level of fear of coronavirus has increased 9 . Studies emphasize the importance of protecting mental health for healthcare workers to fulfil their roles effectively during the pandemic ${ }^{10-12}$. Achieving sustainable success in the provision of healthcare services is closely related to the psychological well-being of healthcare workers ${ }^{13-14}$. However, the COVID-19 can be considered a challenge for psychological resilience ${ }^{15}$.

Turkey has been on the alert with the announcement of the first case infected with coronavirus as part of the fight against COVID-19. Healthcare workers have served intensively in healthcare institutions, intensive care units, home care services, emergency services, and coronavirus test departments. Filiation teams have been assigned to identify patients who have caught coronavirus, to prevent the spread of the disease by identifying other people that these patients have contact with, and to initiate the treatment process of these patients. The filiation teams who work 24 hours a day to monitor COVID-19, visit patients in their homes, give medicines to these people, ensure the transfer of patients or their contacts to the hospital in case of emergency, and regularly monitor how the health status of these people has changed via phone calls ${ }^{12}$.

Studies on the fear and psychological resilience levels of various healthcare workers regarding the COVID19 pandemic can be found in the literature in Turkey ${ }^{12,14}$. However, there are no studies that focus directly on the healthcare workers in the filiation teams, who are most affected by the pandemic and in the highest risk group. This study aimed to investigate the effects of the sociodemographic, organizational, and resilience factors on the fear of COVID-19 of healthcare workers working in the filiation teams in Turkey during the COVID-19 pandemic. Examining the predictors related to the fear of COVID-19 of these critical healthcare workers is of great importance in terms of protecting their well-being. It is expected that the results of this research will provide an important data source for the programs and services required for healthcare workers in the filiation teams to fight and overcome the fear of COVID-19.

\section{MATERIALS AND METHODS}

\section{Design}

This study was carried out in accordance with the principles of the Declaration of Helsinki. This study was approved by Başkent University Social and Human Sciences and Art Ethics Committee in 06.01.2021 (Project number: E-62310886-604.02.01901). Informed consent was obtained from all participants.

The data in the study were obtained with an online form. The data were collected by the researchers through Qualtrics between 15.01.2021 and 15.02.2021. The link created through this website has been delivered to the network of healthcare professionals in the filiation teams. This link directed the participant to a text introducing the research. Once a person has agreed to participate in the study, they were invited to read and accept an informed consent form presented on the first page of the questionnaire. The created online form consists of three screens containing the questionnaire's sections. Participants can return to the previous page while answering the questions.

In the created directive, it was stated to the participants that all questions should be answered. Participants filled the questionnaire in approximately 15 minutes. In order to prevent the participants from filling out this form more than once, IP addresses were checked. Forms sent from the same IP address and giving exactly the same answers were not included in the study due to duplication. Participants were not given a gift or payment for participating in the study. 


\section{Sample}

The universe of the research is composed of the healthcare workers working in the filiation teams in Turkey. There are approximately 22.000 healthcare workers take place in the filiation teams. The number of healthcare workers to be included in the study with the simple random sampling method was determined by the following formula ${ }^{16}$ :

$$
\mathrm{n}=\frac{\mathrm{N} t^{2} p q}{d^{2}(N-1)+t^{2} p q}
$$

$\mathrm{N}$ : Number of individuals in the population (22.000) $\mathrm{n}$ : Number of individuals to be included in the sample p: Incidence frequency (possibility) of the inspected event (0.50)

q: Non-incidence (possibility) of the inspected event (0.50)

$\mathrm{t}$ : The theoretical value found from the $\mathrm{t}$ table at a certain degree of freedom and detected error level $(\mathrm{t}=1.96$ for $\alpha=0.05)$

$\mathrm{d}$ : The intended thing to do based on the incidence frequency of the event \pm deviation (0.05)

1156 healthcare workers were reached via online form. The inclusion criteria of the study were determined as being a health worker and actively taking part in the filiation teams. The exclusion criteria of the study were determined as not taking an active role in the filiation teams and not responding to the entire questionnaire form.128 participants were excluded from the study due to duplication or missing data. The study included 1028 health workers selected.

\section{Measures}

\section{Sociodemographic Questionnaire}

It is related to the profession, gender, age, marital status, having children, educational status, total working time, working department, and the working time in the filiation team, and access to medical equipment during the pandemic.

\section{Fear of COVID-19 Scale}

It was developed by Ahorsu et al. (2020) to measure the fear level caused by the COVID-1917. Its Turkish validity and reliability studies were carried out by Ladikli et al. (2020) ${ }^{18}$. The validity and reliability study of the scale was carried out with the participation of 1176 people in Turkey. The scale consists of seven items with a five-point Likert-type. The internal consistency of the scale was 0.82 and test reliability was 0.72 . It shows that the adapted scale is a reliable measurement tool in determining the fear of COVID-19. The high score obtained from the scale indicates that the fear of COVID-19 is high.

The Resilience Scale for Adults: It was developed by Friborg et al. (2003), and its Turkish adaptation and its validity and reliability studies were conducted by Basım and Çetin (2011) ${ }^{19-20}$. The scale was applied to the sample groups of 350 students and 262 employees. The scale is a five-point Likert type and consists of 33 questions. In the scale, structural style and perception of future are measured with 4 items; family coherence, self-perception and social competence with 6 items, and finally social resources is measured with 7 items. The internal consistency coefficients of the sub-dimensions ranged from 0.66 to 0.81 , and test-retest reliability between 0.68 and 0.81 .

\section{Statistical analysis}

The data were coded and analysed with the SPSS. The effects of the continuous variables and the categorical variables on the fear of COVID-19 were examined. Multiple linear regression models are used to examine the effect of more than one independent variable on a dependent variable ${ }^{21-23}$. In regression analysis, the data collected from different groups are generally wanted to be included in the regression model as a predictor. However, the variables must be continuous or categorical variables with two levels. Point-biserial correlation is the Pearson correlation between a continuous variable and a discontinuous variable whose two categories are encoded as 0 and 1. Simple regression on the other hand is based on Pearson correlation. For this reason, if categorical variable/variables is/are planned to be used as explanatory/predictive variables in multiple linear regression analysis, it should be taken into account that the model can only be created with explanatory/predictive variables with two categories. Discontinuous variables that qualitatively consist of different categories are sometimes analysed after converting them into a set of binary or two-level variables. The process of recategorizing a categorical variable to obtain a set of dichotomous variables is called dummy variable coding. The purpose of this is to limit the relationship between binary variables and 
the others to linear relationships. A discontinuous variable with more than two categories can have any kind of relationship with another variable, and the relationship changes arbitrarily when the numbers assigned to the categories are changed. However, variables with two categories can only have a linear relationship with other variables because they have only two points; therefore, they have analysed appropriately with methods using correlation, in which only linear relationships are analysed ${ }^{24}$.

The discontinuous variables included in the analysis were dummy coded and one of the categories was used as the reference group in each categorical variable. While determining dummy variables, one fewer dummy variable than the number of the categories (k-1) was created in each of the categorical independent variables. The category whose effect is to be examined was coded 1 , and the other categories were coded 0 . The purpose of this is to include only one category for one variable at a time in the analysis and to exclude the effects of other categories. In this way, the effect of the category under the analysis is interpreted according to the excluded reference category ${ }^{25}$. Normality tests are extremely sensitive tests. In addition, measurements of dependent variables do not show normal distribution ${ }^{25}$. The Central Limit Theorem states that if the sample is large enough ( $\mathrm{n} \geq 30$ ), the sampling distribution of the means will be normally distributed regardless of the distribution of the variables, and the normal distribution violation will not cause a major problem ${ }^{25}$. In large samples, skewness does not deviate significantly from normal. Positive kurtosis in a sample size of more than 100 and negative kurtosis in a sample larger than 200 begin to disappear. In line with this information, it was decided that multiple linear regression analysis could be used ${ }^{26}$.

Table 1. The sociodemographic characteristics of the personnel working in the filiation teams

\begin{tabular}{|c|c|c|}
\hline Variable & Frequency & Percent \\
\hline \multicolumn{3}{|l|}{ Gender } \\
\hline Female & 714 & 69.5 \\
\hline Male & 314 & 30.5 \\
\hline \multicolumn{3}{|l|}{ Age groups } \\
\hline $20-29$ & 385 & 37.5 \\
\hline $30-39$ & 304 & 29.6 \\
\hline $40-49$ & 285 & 27.7 \\
\hline $50-59$ & 54 & 5.3 \\
\hline \multicolumn{3}{|l|}{ Educational status } \\
\hline High school & 34 & 3.3 \\
\hline Bachelor's degree & 696 & 67.7 \\
\hline Post graduate & 176 & 17.1 \\
\hline Doctorate & 122 & 11.9 \\
\hline \multicolumn{3}{|l|}{ Marital status } \\
\hline Single & 400 & 38.9 \\
\hline Married & 628 & 61.1 \\
\hline \multicolumn{3}{|l|}{ Population of the region } \\
\hline Under 100.000 & 58 & 5.6 \\
\hline $100.001-1.000 .000$ & 457 & 44.5 \\
\hline $1.000 .001-5.000 .000$ & 408 & 39.7 \\
\hline 5.000 .000 and higher & 105 & 10.2 \\
\hline \multicolumn{3}{|l|}{ Profession } \\
\hline Doctor & 145 & 14.1 \\
\hline Dentist & 110 & 10.7 \\
\hline Nurse & 159 & 15.5 \\
\hline Psychologist and social worker & 111 & 10.8 \\
\hline Healthcare officer & 90 & 8.8 \\
\hline Healthcare technician & 95 & 9.2 \\
\hline Midwife & 218 & 21.2 \\
\hline Other healthcare workers & 100 & 9.7 \\
\hline
\end{tabular}




\section{RESULTS}

The sociodemographic characteristics of the healthcare workers are shown in Table 1. 69.5\% of the participants are females. $37.5 \%$ of them are in the 20-29 age group. $67.7 \%$ of them have bachelor's degrees. $61.1 \%$ are married. Participants consist of midwives $21.2 \%$, nurses $15.5 \%$, doctors $14.1 \%$, psychologists and social workers $10.8 \%$, dentists $10.7 \%$, healthcare officers $9.2 \%$ and healthcare technicians $9.2 \%$. The average age is $34.85 \pm 8.65$.

The effects of the continuous variables and the categoric variables on the fear of COVID-19 were investigated. This analysis was carried out with a stepwise backward multiple linear regression analysis by including the categorical variables after coded as "dummy" variables in the analysis. The analysis was completed in 19 steps. The model fit and the total percentage of the variation explained are shown in
Table 2. It is seen that the model of the variables whose explanatory roles are modelled on the independent variable is significant $(\mathrm{F}=13.991, \mathrm{p}<.05)$. It was decided that the regression model was established as appropriate. The DurbinWatson value, which is the autocorrelation indicator of independent variables, was calculated as 1.973 . If the value obtained as a result of Durbin-Watson analysis is close to 2, it can be said that the model is well-formed. The explanatory rate of the model is $19.10 \%\left(\mathrm{R}^{2}=0.191\right)$. In other words, the explanatory variables' percentage to explain the COVID-19 fear is $19.10 \%$. The adjusted $\mathrm{R}^{2}$ value gives an idea about the generalizability of the model. When the adjusted $\mathrm{R}^{2}$ is examined, it is seen that it has a close value ( 0.177 ) to the observed $\mathrm{R}^{2}$, which indicates that the cross-validity of the model is at a good level. The statistically significant estimates in the best model obtained in the 19th step of the stepwise backward multiple regression are given in Table 3.

Table 2. Regression model fit

\begin{tabular}{|l|l|l|l|l|l|}
\hline $\mathbf{R}$ & $\mathbf{R}^{2}$ & Adjusted R & Durbin-Watson & F & $\mathbf{p}$ \\
\hline 0.437 & 0.191 & 0.177 & 1.973 & 13.991 & 0.000 \\
\hline
\end{tabular}

Table 3. Explanatory variables for fear of COVID-19

\begin{tabular}{|l|l|l|l|l|l|l|l|}
\hline Variables & B & Std.Error & t & p & \multicolumn{2}{l}{ \%95 CI } & VIF \\
\hline Constant & 24.688 & 1.701 & 14.513 & 0.000 & 21.350 & 28.027 & \\
\hline Age & 0.073 & 0.027 & 2.749 & 0.006 & 0.021 & 0.127 & 1.232 \\
\hline Perception of future & -0.374 & 0.075 & -5.006 & 0.000 & -0.520 & -0.227 & 1.696 \\
\hline Family cohesion & 0.146 & 0.050 & 2.945 & 0.003 & 0.049 & 0.243 & 1.219 \\
\hline Perception of the self & -0.159 & 0.065 & -2.460 & 0.014 & -0.286 & -0.032 & 1.708 \\
\hline Gender=Male & -3.027 & 0.479 & -6.317 & 0.000 & -3.967 & -2.087 & 1.145 \\
\hline Education=Doctorate & 2.552 & 1.072 & 2.381 & 0.017 & 0.448 & 4.656 & 2.826 \\
\hline $\begin{array}{l}\text { Presence of an individual with a chronic disease } \\
\text { at home=Yes }\end{array}$ & 1.223 & 0.462 & 2.647 & 0.008 & 0.317 & 2.130 & 1.081 \\
\hline Income=decreased & 1.778 & 0.519 & 3.425 & 0.001 & 0.759 & 2.796 & 1.096 \\
\hline $\begin{array}{l}\text { Having colleague diagnosed with } \\
\text { COVID19=No }\end{array}$ & 2.152 & 0.996 & 2.161 & 0.031 & 0.198 & 4.106 & 1.078 \\
\hline $\begin{array}{l}\text { Having family member dies due to } \\
\text { COVID19=Yes }\end{array}$ & 2.805 & 1.103 & 2.542 & 0.011 & 0.640 & 4.970 & 1.018 \\
\hline Having colleague dies due to COVID19=Yes & 1.453 & 0.462 & 3.144 & 0.002 & 0.546 & 2.360 & 1113 \\
\hline Number of patients=not changed & -1.517 & 0.614 & -2.472 & 0.014 & -2.722 & -0.313 & 1.010 \\
\hline Access to medical equipment & -0.624 & 0.163 & -3.827 & 0.000 & -0.944 & -0.304 & 1.063 \\
\hline
\end{tabular}

VIF shows multicollinearity between predictive variables. When VIF is " 1 ", there is no multicollinearity between predictive variables. There is no strong multicollinearity between predictive variables in the event of $1<\mathrm{VIF} \leq 10$. However, if $\mathrm{VIF}$ is over 10 , then it can be said that there is strong multicollinearity between predictive variables, the model formulated is invalid and a regression model should be formulated with nonparametric or biased estimation methods. It can be said that there is no multicollinearity problem among the variables analysed. Age and family cohesion are positive and significant explanatory factors on the fear of COVID-19 ( $\mathrm{p}<.05)$. 
Perception of future and self-perception from continuous are negatively significant explanatory on the fear of COVID-19 $(\mathrm{p}<.05)$. Increased perception of the future and self-perception will lead to a decrease in fear of COVID-19. Gender is a significant explanatory variable $(\mathrm{p}<.05)$. Males experience COVID-19 fear less than females. Educational status is a significant explanatory variable on fear of COVID-19 $(\mathrm{p}<.05)$. Having a bachelor's degree was taken as the reference group in the analysis. Consequently, being a Ph.D. graduate causes an increase in the fear of COVID-19 when compared to having a bachelor's degree. The presence of an individual with chronic disease at home is a significant explanatory variable $(\mathrm{p}<.05)$. The absence of an individual with chronic illness at home was taken as the reference group. Therefore, having someone with a chronic illness at home increases the fear of COVID-19. The income variable is a significant explanatory variable $(p<.05)$. In the analysis, the income status "did not change" group was taken as the reference group. Decreasing income causes an increase in fear of COVID-19.

Colleague's status of being diagnosed with COVID19 is a significant explanatory variable $(\mathrm{p}<.05)$. The fact that the colleague was not diagnosed with COVID-19 causes an increase in fear of COVID-19. Having a colleague loss due to COVID-19 is a significant explanatory variable $(p<.05)$. Losing a colleague due to COVID-19 causes an increase in fear of COVID-19. Having a family member loss due to COVID-19 is a significant explanatory variable $(\mathrm{p}<.05)$.

Losing a family member due to COVID-19 causes an increase in fear of COVID-19. The number of patients variable is a significant explanatory variable on the fear of COVID-19 ( $<<.05)$. "The number of patients increased" group was taken as the reference group. The number of patients does not change view causes a decrease in the fear of COVID-19 compared to the number of patients increased view. In other words, the increase in the number of patients' views causes an increase in the fear of COVID-19 of healthcare workers. Access to medical equipment is a significant predictor of fear of COVID-19 ( $\mathrm{p}<.05)$. A low score in this variable indicates that there is difficulty in accessing medical equipment while getting a high score indicates easy access. The difficulty in accessing the equipment causes an increase in the fear of COVID-19 of healthcare workers (Table 3).

\section{DISCUSSION}

It was aimed to examine the effects of sociodemographic, organizational, and resilience factors on the fear of COVID-19. First, the effects of sociodemographic characteristics on fear of COVID19 can be examined. It shows that age and family cohesion are positively significant explanatory factors on the fear of COVID-19. This finding of the study can be interpreted as it will increase the fear because the coronavirus is more deadly in elderly people. Hossain et al. also revealed that the fear of COVID19 increases as age increases. Intervention programs can be developed to promote mental health in elderly health workers ${ }^{27}$.

Gender was found as a significant explanatory variable on the fear of COVID-19, and males have less fear of getting coronavirus compared to females. This finding can be explained by the risk-taking behaviours of females are lower than males. Studies similar to this finding of our study can be also found $^{28-30}$.

Education was considered as a significant explanatory variable on the fear of COVID-19. This finding can be interpreted regarding the increase in the behaviour of seeking more information about coronavirus as the education level increases, and thus the level of fear increases. This finding of the study suggests that healthcare professionals accessing information from the right sources can reduce their fear of coronavirus. For this reason, it can be recommended that health professionals access the information provided by official institutions and international health organizations. Income was identified as a significant explanatory variable on the fear of COVID-19. Increasing the income of healthcare workers may be encouraging access to treatment options, access to protective equipment, and access to hygienic materials. Jørgensen et al. stated that as the income level increases, the fear of coronavirus decreases, and the ability to adapt increases ${ }^{31}$.

Factors related to fear of COVID-19 may also be family-related. In this study, the presence of chronic disease at home was considered as a significant explanatory variable on the fear of COVID-19. This finding shows that thought of an individual with a chronic disease at home infected with coronavirus may have more severe symptoms might have increased the fear of COVID-19. The studies reported that participants' concerns about the health of their loved ones, especially those with chronic 
diseases, increased their fear of coronavirus. Taking measures to protect family members against coronavirus (such as access to protective equipment, vaccination against COVID-19) can reduce fear of COVID-1932-33.

The loss of a family member of the healthcare workers due to COVID-19 causes an increase in fear of COVID-19. Shammi et al. stated that the death of a family member due to coronavirus increases the fear of coronavirus ${ }^{34}$.

Factors related to fear of COVID-19 may also be organizational-related. The loss of a colleague of healthcare workers was determined as a significant explanatory variable on the fear of COVID-19. Our study suggests that personnel working in similar healthcare environments increases their vulnerability to coronavirus, where adequate precautions are not taken, which may increase the fear of the possibility of getting coronavirus, just like their colleagues.

The number of patients was found as a significant explanatory variable on the fear of COVID-19. This finding means that, with the increase in the number of patients infected with coronavirus and the caseload, healthcare workers have more contact with patients and take higher risks. Lai et al. stated that healthcare workers who constantly care for patients are at a higher risk of contracting infectious diseases and that this has a heavy psychological cost ${ }^{35}$. Limiting the caseload of health workers in certain ways, and working by health workers taking leave and taking breaks can positively affect mental health.

The healthcare workers' access to medical equipment during the pandemic was identified as a significant explanatory variable on the fear of COVID-19. Failure of healthcare workers to access adequate equipment during medical interventions may increase fears of COVID-1934-37. So it is essential that healthcare workers have access to the medical equipment they need.

Finally, the effect of resilience factors on fear of COVID-19 can be examined. The perception of the future and self-perception were determined as negatively significant explanatory variables on the fear of COVID-19. This finding can be interpreted as healthcare workers' perception of the future within a positive framework, and their strengths such as selfconfidence and self-discipline will be effective in reducing the fear of COVID-19. Psychoeducation programs can be developed to increase selfconfidence and self-discipline in health workers.
This study has some limitations. First of all, the generalization of the results to Turkey may lead to wrong evaluations due to the cross-sectional design and the use of a simple random sampling method. Our manuscript as currently written presents an exploratory and descriptive study of demographic characteristics. The research questions were tested using single-survey, self-report data collected from the same individuals at one point in time. Second, the study was carried out within a certain cross-section in terms of duration. Third, this study was conducted through an internet survey which might reduce the comprehensive understanding of scale items.

The results of our study show that age and family cohesion are positively significant, while the planned future and perception of self is negatively significant explanatory factors on the fear of COVID-19. It was determined that the fear of COVID-19 is higher in females, and in those with a high level of education, those who have an individual with a chronic disease at home, those with a low-income level, those who lost a colleague and a family member due to coronavirus, those who have an increase in patient burden, and those who have problems in access to medical equipment. In the period of the COVID-19 pandemic, it is vitally important to protect the psychological well-being of healthcare workers in the filiation team, who maintain quarantine and infection control practices at the forefront for both the control of the disease and the recovery of the society. Therefore, we suggest that the adoption of psychosocial support mechanisms and mental health services, in which protective factors affecting the fear of COVID-19 are strengthened and the risks are reduced, play a key role for the healthcare workers in filiation teams. Services provided in the psychosocial field can be provided to healthcare professionals at individual, organizational and familial levels. Besides, it is recommended to improve organizational conditions (such as reducing the caseload, accessing medical equipment, increasing income level).

\footnotetext{
Yazar Katkıları: Calısma konsepti/Tasarımı: MDPG, MK, VD; Veri toplama: MDPG, MK, VD, HFÖ; Veri analizi ve yorumlama: VD, HFÖ; Yazı taslağı: MDPG, MK, VD; İçeriğin eleştirel incelenmesi: VD; Son onay ve sorumluluk: MDPG, MK, HFÖ, VD; Teknik ve malzeme desteği: -; Süpervizyon: MDPG, MK, VD, HFÖ; Fon sağlama (mevcut ise): yok.

Etik Onay: Bu calısma için Baskent Üniversitesi Akademik

Değerlendirme Koordinatörlüğü tarafindan 31.12 .2020 tarih ve

17162298.600-483 sayll kararı ile etik onay alınmıştır.

Hakem Değerlendirmesi: Dış bağımsız.

Çıkar Çatışması: Yazarlar çıkar çatışması beyan etmemişlerdir.

Finansal Destek: Yazarlar finansal destek bevan etmemislerdir.

Author Contributions: Concept/Design : MDPG, MK, VD; Data

acquisition: MDPG, MK, VD, HFÖ; Data analysis and interpretation:

VD, HFÖ; Drafting manuscript: MDPG, MK, VD; Critical revision of
} 
manuscript: VD; Final approval and accountability: MDPG, MK, HFÖ, VD; Technical or material support: -; Supervision: MDPG, MK, VD, HFÖ; Securing funding (if available): $\mathrm{n} / \mathrm{a}$.

Ethical Approval: Ethical approval was obtained for this study by the Başkent University Academic Evaluation Coordination Office with the decision No. 17162298.600-483 dated 31.12.2020.

Peer-review: Externally peer-reviewed.

Conflict of Interest: Authors declared no conflict of interest

Financial Disclosure: Authors declared no financial support

\section{REFERENCES}

1. Jahrami H, BaHammam, AS, Al Gahtani H, Ebrahim $\mathrm{A}$, Faris $\mathrm{M}, \mathrm{Al}$ Eid $\mathrm{K}$ et al. The examination of sleep quality for frontline healthcare workers during the outbreak of Covid-19. Sleep Breath. 2021;25:503-11.

2. Huang Y, Zhao N. Generalized anxiety disorder, depressive symptoms and sleep quality during Covid19 outbreak in China: a web-based cross-sectional survey. Psychiatry Res. 2020;288:112954.

3. Almaghrabi RH, Huda A, Al HWA, Albaadani,MM. Healthcare workers experience in dealing with coronavirus (Covid-19) pandemic. Saudi Med J. 2020;41:657-60.

4. Lasalvia A, Bonetto C, Porru S, Carta A, Tardivo S, Bovo C, Amaddeo F. Psychological impact of Covid19 pandemic on healthcare workers in a highly burdened area of north-east Italy. Epidemiol Psychiatry Sci. 2021;30:e1.

5. Hall $\mathrm{H}$. The effect of the Covid-19 pandemic on healthcare workers' mental health. JAAPA. 2020;33:45-8.

6. Shechter A, Diaz F, Moise N, Anstey DE, YS, Agarwal S, Abdalla M. Psychological distress, coping behaviors, and preferences for support among New York healthcare workers during the Covid-19 pandemic. Gen Hosp Psychiatry. 2020;66:1-8.

7. Du J, Dong L, Wang T, Yuan C, Fu R, Zhang L, Li X. Psychological symptoms among frontline healthcare workers during Covid-19 outbreak in Wuhan. Gen Hosp Psychiatry. 2020;64:144-5.

8. Dai Y, Hu G, Xiong H, Qiu H, Yuan X. Psychological impact of the coronavirus disease 2019 (Covid-19) outbreak on healthcare workers in China. MedRxiv. 2020; doi: 10.1101/2020.03.03.20030874.

9. Ornell F, Schuch JB, Sordi AO, Kessler FHP. "Pandemic fear" and Covid-19: mental health burden and strategies. Braz J Psychiatry. 2020;42:232-5.

10. Greenberg N, Docherty M, Gnanapragasam S, Wessely S. Managing mental health challenges faced by healthcare workers during Covid-19 pandemic. BMJ. 2020;368:m1211.

11. Walton M, Murray E, Christian MD. Mental health care for medical staff and affiliated healthcare workers during the Covid-19 pandemic. Eur Heart J. 2020;9:241-7.

12. Pala SÇ, Metintas S. Covid-19 pandemisinde sağllk çalışanları. ESTÜDAM Halk Sağllğı Dergisi. 2020; 5(Özel Say1):175-87.
13. Low JG, Wilder-Smith A. Infectious respiratory illnesses and their impact on healthcare workers: a review. Ann Acad Med Singapore. 2005;34:105-10.

14. Bozdă̆ F, Ergün N. Psychological resilience of healthcare professionals during COVID-19 pandemic. Psychol Rep. 2020; doi: 10.1177/0033294120965477..

15. Smith GD, Li WHC. COVID-19: Emerging compassion, courage and resilience in the face of misinformation and adversity. J Clin Nurs. 2020;29:1425.

16. Cohen J. Statistical Power Analysis for The Behavioral Sciences. Baltimore, Academic Ppress, 2003.

17. Ahorsu DK, Lin CY, Imani V, Saffari M, Griffiths MD, Pakpour AH. The fear of Covid-19 scale: development and initial validation. Int J Mental Health Addict. 2020; doi: 10.1007/s11469-020-002708.

18. Ladikli N, Bahadır E, Yumuşak FN, Akkuzu H, Karaman G, Türkkan Z. Kovid-19 Korkusu Ölçeği'nin Türkçe güvenirlik ve geçerlik çalışması. Uluslararas1 Sosyal Bilimler Dergisi. 2020;3:71-80.

19. Friborg $\mathrm{O}$, Barlaug D, Martinussen M. Resilience in relation to personality and intelligence. Int J Methods Psychiatr Res. 2005;14:29-42.

20. Basim HN, Çetin F. Yetişkinler için Psikolojik Dayanıklılık Ölçeği’nin güvenilirlik ve geçerlilik çalışması. Turk Psikiyatri Derg. 2011;22:104-14.

21. Cohen J, Cohen P, West SG, Aiken LS. Applied Multiple Regression, Correlation Analysis For The Behavioral Sciences. Matwah, Lawrence Erlbaum Associates, 2003.

22. Field A. Discovering Statistics Using IBM SPSS Statistics. London, Sage, 2018.

23. Pedhazur EJ. Multiple Regression in Bihavoral Research: Explanation and Prediction TX, Holt Rinehart and Winston, 1997.

24. Tabachnick BG, Fidell LS. Using Multivariate Statistics (6th ed). Boston, MA, Allyn and Bacon, 2013.

25. Xie Y, Powers D. Statistical Methods for Categorial Data Analysis. San Diego, Academic Press, 2000.

26. Pallant J. SPSS Survival Manual. New York, McGrawHill Education, 2016.

27. Hossain MA, Jahid MIK, Hossain KMA, Walton LM, Uddin Z, Haque MO et al.. Knowledge, attitudes, and fear of Covid-19 during the Rapid Rise Period in Bangladesh. PloS one. 2020;15:e239646.

28. Tekin Atay Ü, Dinçer NN, Yarkac FU, Elif Ö. Covid19 pandemi sürecinde diş hekimliği uzmanlık öğrencilerinin korku ve anksiyete düzeylerinin değerlendirilmesi. Necmettin Erbakan Üniv Diş Hekimliği Derg. 2020;2:86-93.

29. Doshi D, Karunakar P, Sukhabogi JR, Prasanna JS, Mahajan SV. Assessing coronavirus fear in Indian population using the fear of Covid-19 scale. Int J Ment Health Addict. 2020; doi: 10.1007/s11469-020-00332$\mathrm{x}$. 
30. Sakib N, Bhuiyan AI, Hossain S, Al Mamun F, Hosen I, Abdullah AH, Mamun MA. Psychometric validation of the Bangla fear of Covid-19 scale: confirmatory factor analysis and rasch analysis. Int J Mental Health Addict. 2020; doi: 10.1007/s11469-020-00289-x.

31. Jørgensen F, Bor A, Petersen MB. Compliance without fear: Individual-level protective behaviour during the first wave of the COVID-19 pandemic. $\mathrm{Br}$ J Health Psychol. 2021;26:679-96.

32. Hatun $\mathrm{O}$, Dicle AN, Demirci İ. Koronavirüs salgınının psikolojik yansımaları ve salgınla başa çıma. Electronic Turkish Studies. 2020;15:531-54.

33. Mertens G, Gerritsen L, Duijndam S, Salemink E, Engelhard IM. Fear of the coronavirus (Covid-19): predictors in an online study conducted in march
2020. J Anxiety Disord. 2020;74:102258.

34. Shammi M, Bodrud-Doza M, Islam ARMT, Rahman MM. Covid-19 pandemic, socioeconomic crisis and human stress in resource-limited settings: a case from Bangladesh. Heliyon. 2020;6:e04063.

35. Lai J, Ma S, Wang, Y, Cai Z, Hu J, Wei N et al. Factors associated with mental health outcomes among health care workers exposed to coronavirus disease 2019. JAMA. 2020;3:e203976.

36. Ehrlich H, McKenney M, Elkbuli A. Protecting our healthcare workers during the Covid-19 pandemic. Am J Emerg Med. 2020;38:1527-8.

37. Cawcutt KA. Starlin R, Rupp ME. Fighting fear in healthcare workers during the Covid-19 pandemic. Infect Control Hosp Epidemiol. 2020;41:1192-3. 